\title{
Demir Çelik Sektöründe İş Kazalarının Çeşitli Faktörlere Göre Analizi
}

\author{
Analysis of Work Accidents According to Various Factors in Iron and Steel Industry
}

\author{
Burcu ÖZCAN (iD) , Gözde BECEREN
}

\section{ÖZET}

Günümüzde iş sağlığı ve güvenliği bir işletmedeki en önemli faktörlerden biridir. İş sağlığı ve güvenliğine verilen değer işletmenin imajına katkı sağlamakta, çalışanların moral ve motivasyonunu yükseltmekte, alınan önlemlerle birlikte iş kazalarını olabildiğince engellemeye çalışmakta ve uzun sürede meslek hastalığına karşı çalışanlarını koruma amacı taşımaktadır. İş kazalarının ne zaman hangi koşullarda ortaya çıkacağı önceden öngörülememektedir. Bir işletmedeki en önemli faktör insan olduğu için insanın hayatını korumak her zaman ön plana çıkmaktadır. Çalışanların sağlığı ve güvenliği için de sürekli olarak iş güvenliği önlemleri alınmalıdır. Bu çalışmada ise gerekli önlemlerin daha iyi alınabilmesi için iş kazalarının şiddeti ile işçinin kıdeminin, kazanın gerçekleştiği bölümün, kazanın gerçekleştiği çalışma saatinin ve kazanın gerçekleştiği vardiyanın ilişkisi incelenmektedir. Yapılan analiz sonucunda çalışmanın yapıldığı çelik üretim fabrikasında iş kazalarının şiddetinin kazanın gerçekleștiği saate göre farklılık gösterdiği ortaya konulmuştur.

Anahtar Kelimeler: İstatiksel Analiz, İș Güvenliği, İș Kazası

\section{ABSTRACT}

Occupational health and safety is one of the most important factors in a business today. The value attached to occupational health and safety contributes to the image of the company, increases the morale and motivation of the employees, tries to prevent occupational accidents as much as possible with the measures taken and aims to protect the employees against occupational diseases in a long time. It is unpredictable when and under what conditions work accidents will occur. Since the most important factor in a business is people, protecting one's life always comes to the fore. Occupational safety measures should be taken continuously for the health and safety of the employees. In this study, in order to take the necessary precautions better, the severity of work accidents and the seniority of the worker, the part of the accident, the working hours of the accident and the shift of the accident are examined. As a result of the analysis, it was revealed that the severity of work accidents varies according to the time of the accident in the steel production factory where the study was conducted.

Keywords: Statistical Analysis ,Occupational Safety, Occupational Accident

Burcu ÖZCAN I burcu.ozcan@kocaeli.edu.tr

Kocaeli Üniversitesi, Mühendislik Fakültesi, Kocaeli, Türkiye

Kocaeli University, Faculty of Engineering, Kocaeli, Turkey

Gözde BECEREN (Sorumlu Yazar/Corresponding Author) | gozdebecerenn@gmail.com

Kocaeli Üniversitesi, Mühendislik Fakültesi, Kocaeli, Türkiye

Kocaeli University, Faculty of Engineering, Kocaeli, Turkey 


\section{GİRIŞ}

Küreselleşen dünya ile özellikle 21. yüzyılda iş sağlığı ve güvenliği kavramı oldukça değer kazanmış ve bu konuyla ilgili önlemler alınmaya başlanmıştır. Firmalar arasında gittikçe artmakta olan rekabet ortamı da işletmelerin iş güvenliği ve sağlığı konusunda çalışmalar yapmasını hızlandırmıştır. İş güvenliği kavramı çok eski zamanlardan beri var olsa da insan faktörünün öneminin giderek artmasıyla değer ve anlam kazanmaktadır. İş güvenliği kavramının bu ivme ile değer kazanmasında sanayileşmenin payı oldukça büyüktür. Sanayide gerçekleşen yenilikler, yeni makinelerin ortaya çıkması ve üretimin gelişmesi insan ve üretim araçlarının uyum içinde çalışmasını gerektirmektedir. Bu uyum sağlanırken de hatalardan ya da koşullardan kaynaklı olarak iş kazaları ortaya çıkabilmektedir $[1,2]$.

İş kazaları için alınan önlemler iş kazalarının sayısını minimuma indirmeyi ve ortaya çıkabilecek etkilerin olabildiğince düşük seviyede tutulabilmesini sağlama amacını taşımaktadırlar. İş kazaları güvensiz hareketler ve güvensiz koşullardan kaynaklanmaktadır.

Güvensiz hareketler kişisel koruyucu ve donanımları kullanmama veya yanlış kullanılması, malzemelerin hatalı kullanılması, yüklemelerin emniyetsiz yapılması, makine ve teçhizatların uygunsuz şekilde kullanılması, makine ve teçhizatların temizlenmesinin makineler durdurulmadan gerçekleştirilmesi, el şakalarının yapılması gibi durumlardan oluşmaktadır. Güvensiz koşullar ise kişisel makine ve koruyucu donanımların yetersiz olması, çalışma ortamının uygunsuz koşullara sahip olması, yetersiz havalandırma ve aydınlatma, gereksiz ve önüne geçilemeyen gürültü gibi durumlardan oluşmaktadır. Güvensiz hareketlerden bizzat çalışan sorumluyken güvensiz koşullardan işveren sorumlu tutulmaktadır [3].

İş kazaları sonucunda meydana gelen zararlar bulun- maktadır ve bu zararlar maddi ve manevi olarak ikiye ayrılmaktadır. Manevi zararlar hem kazayı geçiren kişinin ailesini hem de işvereni ve işletmede iş sağlığı ve güvenliğinden sorumlu kişiyi etkilemektedir. Bunun yanı sıra kazayı geçiren kişinin çalışma arkadaşları da manevi olarak fazlasıyla zarar görmektedir. İş kazası sonucunda maddi zararlar iki sınıfa ayrılmaktadır ve bu sınıflar doğrudan ve doğrudan olmayan (dolaylı) zararlardan oluşmaktadırlar. Dolaylı zarar hesabının yapılması zor olmaktadır. Bunun yanı sıra Uluslararası Çalışma Örgütü verileri incelendiğinde sanayileşmiş ülkelerde gerçekleşen iş kazaları ve ortaya çıkan meslek hastalıklarının maliyetlerinin toplamının, bu ülkelerin gayrı safi yurt içi hasılalarının \%1' i ile \%3' ü oranında değişiklik gösterdiği sonucuna varılmaktadır. Hala gelişimine devam eden ülkelerde bu kayıpların gayri safi yurt içi hasılanın \% 4' ü kadar olduğu tahmin edilmektedir [4].

Literatürde iş sağlığı güvenliği ve iş kazaları konularında gerçekleştirilmiş çok sayıda çalışma bulunmaktadır. Bu çalışmalardan bazıları aşağıda özetlenmiştir. İlk olarak inşaat sektöründe yapılan çalışmalar yer almaktadır.

Ekinci(2020), iş sağlığı ve güvenliği konusundaki temel kavramlardan yola çıkarak Türkiye'deki yapı işlerinde iş sağlığı ve güvenliği hakkında genel bir bilgi sunmuş ve Türkiye'de son yılların en önemli projelerinden biri olan Ankara-Sivas yüksek hızlı tren hattında çalışanların iş sağlığı ve güvenliği konularına değinmiştir. Ekinci bu kapsamda özel olarak yüksek hızlı tren şantiyesini ve kamp alanında yapılan iş sağlığı ve güvenliği uygulamalarını detaylıca araştırmıştır. Yüksek hızlı tren şantiyesinde iş sağlığı ve güvenliği adına yapılan uygulamaların özellikle iş kazaları açısından olumlu sonuçlar ortaya çıkardığını görmüştür [5].

Uzun(2020), inşaat sektöründe iş sağlı̆̆ ve güvenliğinin çok önemli olduğunu öne sürmüş ve şu anda günümüzde iş sağlığı güvenliği adı altında yönetim standartları bulunmasına rağmen bu standartların özellikle inşaat sektö- 
ründe sıkça yer kaplayan proje bazlı, geçici süreli işlere uygun olmadığını, inşaat projelerinin tüm özelliklerini kapsayan bir iş sağlı̆̆ı güvenliği standardının bulunmadığını düşünmüştür. Çalışmasını yeni bir iş sağlığı güvenliği sistem önerisi üzerinde yapmış ve bu sistemi tasarlarken uzman görüşler yardımıyla sistem kriterlerini analitik hiyerarşi prosesi yöntemi ile ağırlıklandırmıştır. Uzun, çalışmasında inşaat sektöründe yer alan iş güvenliği uzmanlarının alınan tedbirler hakkında görüşlerini araştırmış ve uzmanların iş kazalarının azaltılmasına yönelik yaklaşımlarını değerlendirmiştir [6].

Gürsoy (2019), son yıllarda yaşanan iş kazalarının önemli bir oranın inşaat sektörlerinde meydana geldiğini görmüş ve iş kazaları sonucu oluşan ölüm ve yaralanmaların iş sağlığı ve güvenliğini bu sektörde ön plana çıkardığını fark etmiştir. Gürsoy çalışmasında, iş sağlığı ve güvenliği eğitimlerinin inşaat sektöründe çalş̧anlar üzerindeki etkisini ve önemini belirlemek üzere anket araştırmasıyla inşaat sektöründe yaşanan kazalar ile bu kazaları yaşayan kişiler hakkında eğitim, sağlık, yaş grubu, tecrübe ve çalışanların iş güvenliği bilgilerini değerlendirmiştir [7].

Güllüoğlu (2019), çalışmasında Sosyal Güvenlik Kuru$\mathrm{mu}$ tarafından yayınlanmakta olan istatistik yıllıkları çalışmasının 2008-2017 verilerini kullanarak inşaat sektöründe istihdamı ve meydana gelen iş kazalarını analiz etmiştir. Verileri genel ve ölümlü kaza sıklığı, sürekli iş görmezlik ve geçici iş görmezlik kaza sıklığı, standardize iş kazası ora$\mathrm{n} ı$, iş kazası sıklık hızı ve iş kazası ağırlık hızı parametrelerini göz önünde bulundurarak değerlendirip inşaat sektöründe gerçekleşen değişimleri grafiklerle ve tablolarla incelemiştir [8].

Korkmaz (2017), çalışması ile maddi ve manevi büyük kayıplara neden olan ve ağırlıklı olarak inşaat ve maden iş kollarında meydana gelen kazaların sebeplerinin doğru olarak tespiti ile ilgili yöntemler ve önleme faaliyetleri ile bu yöntemler arasındaki sistematik ilişkinin ortaya konulması ve kazaların kusur dağılımının yapılmasında bir modele ihtiyaç olup olmadığının değerlendirmesini amaçlamıştır. Korkmaz önleme faaliyetlerinin başarısız olmasının kazaları doğurduğunu öne sürmüştür. Kazalar sonucu çalışanın sağlığının bozulması, hayatını ya da uzvunu kaybetmesi gibi onarılması mümkün olmayan zararlar ile hasarlar ortaya çıktığını belirtmiştir. Kazaların da sürekli gelişmeye dayalı İSG yönetim sisteminin kurulmayışından kaynaklandığını ileri sürmüştür [9].

Üretim fabrikaları üzerinde yapılan bazı çalışmalardan aşağıda bahsedilmiştir.

Yıldırım (2019), çalışmasında işs sağlığı güvenliği kavramının öneminden bahsetmiş ve kireç üretimi yapan bir fabrikanın sürecini iş sağlığı güvenliği standartlarına göre değerlendirerek bir örnek teşkil etmesini istemiştir. Yıldırım çalışmasında ISO 14001 ve OHSAS 18001 Yönetim Sistemlerini birlikte kullanmış ve her iki standardı tek tek anlatmıştır [10].

Halıcı ve İşleyen (2019), çalışmalarında elektrik kaynaklı iş kazalarının meydana gelmesinde etkili olan faktörler üzerinde analizler yapmışlardır. Analitik hiyerarşi prosesi ile kazanın oluşmasında öncelikli olan faktörü belirlemek için üç temel faktörü ve bunlara ilişkin 46 alt kriteri baz almışlardır. Yaptıkları çalışma sonucunda iş şartlarına uygun bir tasarımın yapılmasının önemli olduğunu fark etmişlerdir [11].

Kuşdemir (2018), çalışmasında bir mobilya endüstrisinde iş-üretim-iş̧i sağlığı analizi yapmıştır. Çalışmada rastgele örnekleme yöntemi kullanılarak seçilen 10 iş yerinden toplam 130 çalışanla görüşsüşsür. Ahşap sanayinde çalışan kişilerin \%13,07' si iş kazasına uğradığı ve \% 4,61 'inin meslek hastalığına yakalandığını tespit etmiştir [12]. 
Yeşilgöz (2018), döküm üretimi üzerinde iş sağlığı ve güvenliği çalışması gerçekleştirmiştir. Yeşilgöz’e göre dökümle üretilen ürünler birçok sektörde yer almaktadır. Döküm sektörünün proseslerinden kaynaklı iş kazaları ve meslek hastalıkları çoğunlukla bu sektörde görülmektedir. Döküm ve döküm sektörü tehlikeli işlerden olmakla birlikte sektörde çalışanların sağlığını etkileyen çok sayıda etmene sahiptir ve bu çalışmada Yeşilgöz bu etmenleri incelemiştir. Yeşilgöz çalışmasında, belirlediği fabrikalarda çalışanlara anket formu düzenlemiş ve elde edilen verilerden yola çıkarak dökümhanelerde iş sağlığı güvenliği uygulamalarının profilini oluşturmuştur [13].

Ertürk (2017), bir fabrikada çalışanların psikolojik durumunun ve uykulu olma halinin iş kazası ortaya çıkarıp çıkarmama durumuna etkilerini incelemiştir [14].

Yabanova (2016), gece vardiyasının iş̧̧ileri ne şekilde etkilediğini, işçilerin fizyolojik, sosyolojik ve psikolojik olarak ne tepkiler gösterdiğini ve iş kazalarının etkilerinin incelenmesini konu alan bir çalışma gerçekleştirmiştir [15].

Kanlıoğlu (2015), çalışmasında sanayide ve birçok alanda kullanılan basınçlı gaz tüplerinin önemini vurgulamış ve çevresine tehlike teşkil ettiğini ileri sürmüştür. Gaz tüplerinin hatalı kullanımından dolayı birçok iş kazası ortaya çlktığını fark eden Kanlıŏlu bu çalışmasında basınçlı gaz tüplerini iş sağlığı güvenliği açısından incelemiş ve kullanımı sırasında ortaya çıkan risklere çözüm önerilerini sunmuştur [16].

Özçatalbaş (2014),çalışmasında iş kazalarının kök sebep analizi ile incelenmesini gerçekleştirmiştir. Kök Sebep Analizi Metodu' nun, Bakü Tiflis Ceyhan Boru Hattı Türkiye kısmı işletmecisi olan Botaş International Limited şirketinin Erzurum'da bulunan pompa istasyonunda meydana gelen bir proses kazasına uygulanması sonucu bulunan kök sebepleri irdelemiş ve aynı veya benzer kazaların meydana gelmesini engellemek amacı ile şirket yönetimince alınması gereken aksiyonlara ışık tutmak amacı ile tavsiyeler hazırlayarak çalışmasını tamamlamıştır [17].

Gülhan (2008), çalışmasında metal üretim fabrikasında iş kazası sıklığı ve buna bağlı faktörleri incelemiştir. Çalışmasında verilerini işçilere anket uygulayarak toplamıştır. Çalışmasının sonucunda metal işçilerinin \% 22,4' ünün iş kazası geçirdiğini ve iş̧̧ilerin iş kazası geçirme sıklığının yaş gruplarına göre dağılımında istatistiksel farklılıklar olduğunu, kaza geçirme sıklığının da medeni duruma göre farklılık gösterdiğini belirmiştir [18].

Yapılan diğer çalışmalardan bazıları ise aşă̆ıdaki gibidir.

Karabulut (2018), çalışmasında iş sağlığı ve güvenliği yönetmeliklerinde yer alan maddelerin kurumlarda ne düzeyde gerçekleştirildiklerini incelemiştir. Üniversitelerde, belediyelerde ve sağlık kuruluşlarında bulunan iş sağlığı güvenliği uzmanları ile bir anket yapmış ve verilerini elde etmiştir. Elde ettiği verileri çalışmasında analiz ederek yorumlamıştır. [19]

Gül(2017), bu çalışmanın amacını OSGB'lerde görevli personelin yasal düzenlemelerden ve çalışma ortamındaki uygulamalardan kaynaklanan sorunları ve bu sorunların çözüm önerileri incelemek olarak belirlemiştir. Çalışmada OSGB kurulabilmesi için gerekli fiziki şartlar ve yasal dayanak kurulumu için başvuru işlemlerinde izlenecek prosedürler, birimin yetkilendirilme süreci, çalışma usul ve esasları, bu birimlerden hizmet alımı ve bu birimler için ihtar ve uyarılar gibi konular ile ilgili bir inceleme yapmıştır [20].

İş kazalarının önlenmesi için ne tür önlemler alınacağına katkı sağlamak, iş kazalarını etkileyen faktörlerin incelenmesini gerçekleştirmek amacıyla bu çalışma ortaya konulmuştur. İş kazalarının incelenmesinde iş kazasının hangi 
vardiyada ve çalışmanın kaçıncı saatinde meydana geldiği, kazanın fabrikanın hangi bölümlerinde gerçekleştiği, kazayı yaşayan çalışanın kaç senedir orada çalışan olduğu gibi faktörler bulunmaktadır. Kazanın şiddeti ve belirlenen faktörler arasındaki ilişki analiz edilmiştir.

\section{II. İSTATISTTIKSEL YÖNTEM}

Verilerin sistemli bir şekilde bir amacı gerçekleştirmek için belirlenen yöntemler yardımıyla toplanması, incelenerek analiz edilmesi ve sonuçların yorumlanmasına bilimsel çalışma süreci denilmektedir. Bilimsel araştırmalarda genellikle kuramlara dayanılmakta daha sonra hipotezler öngörülerek test edilmekte, sonuçlar bilimsel olarak ortaya çıkarılmakta ve son olarak bu sonuçların yorumlanması gerçekleştirilmektedir [21].

Araştırmada ilk olarak veriler elde edilmekte ve bu aşamadan sonra istatistiksel testleri gerçekleştirmek için hipotezler oluşturulmaktadır.

İstatistiksel testlerin seçiminde her testin kendine ait şartları bulunmaktadır ve bu koşullara göre test seçimi gerçekleştirilmektedir. Test seçimi için Tablo 1 oluşturulmuştur $[22,23]$.

Veri analizinde istatistiksel testler iki sınıfa ayrılmaktadır. Bu testler verinin türüne ve ölçek tipine, verinin dağı-

Tablo 1: Uygulanacak istatistiksel testin seçimi

\begin{tabular}{|c|c|c|c|}
\hline $\begin{array}{l}\text { Grup } \\
\text { Sayısı }\end{array}$ & $\begin{array}{c}\text { Grup } \\
\text { Durumu }\end{array}$ & Varsayımlar & Kullanılacak Test \\
\hline 2 & Bağımsız & $\begin{array}{c}4 \text { varsayım da karşılanı- } \\
\text { yorsa }\end{array}$ & Bağımsız t testi \\
\hline 2 & Bağımsız & $\begin{array}{c}4 \text { taneden biri ihmal } \\
\text { edilmişse }\end{array}$ & $\begin{array}{c}\text { Mann-Whitney U } \\
\text { testi }\end{array}$ \\
\hline 2 & Bağımlı & $\begin{array}{l}\text { En az } 1 \text { ve } 2 \text {. varsayım- } \\
\quad \text { lar karşılanıyorsa }\end{array}$ & Bağımlı $t$ test \\
\hline 2 & Bağımlı & $\begin{array}{c}\text { 1.ya da } 2 \text {. varsayım ihlal } \\
\text { edilmişse }\end{array}$ & Wilcoxon testi \\
\hline 2 & & $\begin{array}{l}\text { Nominal veri kullanıl- } \\
\text { mışsa }\end{array}$ & Ki-kare testi \\
\hline $3^{+}$ & Bağımsız & $\begin{array}{c}4 \text { varsayım da karşılanı- } \\
\text { yorsa }\end{array}$ & ANOVA testi \\
\hline $3^{+}$ & Bağımsız & En az biri ihlal edilmişse & $\begin{array}{c}\text { Kruskal-Wallis } \\
\text { testi }\end{array}$ \\
\hline
\end{tabular}

lım şekline ve test edilmesi gereken hipoteze göre parametrik testler ve nonparametrik testler olarak tanımlanmaktadır. Bir test modelinin öngördüğü şartlara testin varsayımları denilmektedir. Bir testin varsayımının güçlü ve kapsamlı olması testin kuvvetli olduğunu göstermektedir. Parametrik testler güçlü varsayımlara sahiptirler. Ana kitle hakkında yeterli bilgi olmadığında ya da hiçbir şey bilinmediğinde nonparametrik testler kullanılmaktadır. Nonparametrik testler parametrik testlere göre kullanım ve uygulama açısından çok daha kolay olmaktadır fakat aynı koşullar alıında parametrik testler nonparametrik testlerden çok daha güçlüdürler.

Parametrik testlerin kullanılması için dört tane varsayım bulunmaktadır.

1-Veriler normal dağılıma uygunsa

2-Örneklem sayısı 30' dan büyükse

3-Veriler ölçümle elde edilmişse

4-Verilerin varyansları homojense parametrik testler kullanılmaktadır [23].

İstatistiksel testler uygulanırken genellikle tümevarım yöntemi kullanılmakta ve bunun sonucunda çıan ifadelerde bir belirsizlik bulunmaktadır. Bu belirsizlik tamamen ortadan kaldırılamamakta fakat istenen bir sınır içinde tutulabilmektedir. Gözlem sayısının arttırılması, daha çok deneme yapılması, rastgeleliğin kontrol altına alınması ile belirsizlik sınırlar içinde tutulabilmektedir. Belirsizlik derecesine güvenirlik derecesi denilmekte, bu derece araştırma ve araştırmanın amacına göre kullanılmaktadır. Genelde araştırmalarda en çok kullanılan güvenirlik derecesi \%10, $\% 5$ ya da \%1 olmaktadır [24]. İstatistikte ortaya çıkan bu belirsizlik yüzünden yanlış varsayımı doğru kabul etme ya da gerçekte doğru olan bir varsayımı yanlış olarak kabul etme durumları ortaya çıkabilmektedir. Doğru varsayımı reddetmek 1.tip hata, yanlış varsayımı kabul etmek de 2.tip 
hata olarak bilinmektedir. 1.tip hata $\alpha$ ve 2.tip hata $\beta$ sembolleri ile gösterilmektedir [24].

Parametrik testlerin uygulanması için gerekli bir varsayım verilerin normal dağılıma uygun olmasıdır. Bu kontrolün sağlanması için normallik testleri bulunmaktadır. Ki kare uyum iyiliği testi örneğin geldiği yığının dağılımını belirlemek için kullanılmaktadır. Diğer bir normallik testi olarak kullanılan Kolmogorov-Smirnov testi eşit aralıklı düzeyde ölçülmüş değerler için kullanılmaktadır. Eğer Kolmogorov-Smirnov testinin önceden tahmin edilen normal dağılımının parametreleri hakkında bilgi yoksa ve bu parametreler örnek üzerinden tahmin edilerek bulunuyorsa Lilliefors normallik testi uygulanmaktadır. Örnek veri parametreleri bilinmeyen bir normal dağılımdan geliyorsa Shapiro-Wilk normallik testi kullanılmaktadır. Normal dağılıma uygunluk testleri gerçekleştirildikten sonra diğer bir varsayım olan varyans homojenliğine bakılmaktadır. Varyans homojenliğini test etmek için Levene testi kullanilmaktadır.

En çok kullanılan parametrik testler z testi,t testi ve one -way anova testi olarak bilinmektedir. $Z$ testi ve $t$ testi örneklem ortalamasına dayanmaktadır. $\mathrm{T}$ testi ortalamalar arasında fark olup olmadığını önemli derecede belirlemekte ve iki farklı ortalama ya da değeri karşılaştırmaktadır. Özellikle örneklem büyüklüğü az, örneklemin alındığı ana kütlenin standart sapması bilinmiyorsa ve ana kütlede hipotez testi kullanılamıyorsa t testi kullanılmaktadır. Tek kuyruklu ya da çift kuyruklu olabilmektedir. Çift kuyruk t testinde bir grubun ortalamasının diğer grubun ortalamasından farkının hangi yönde olduğu önemsenmemekte ve bu fark pozitif ya da negatif yönde olabilmektedir. Ancak tek kuyruk t testinde iki grubun ortalama farkının belli bir yönde farklı olması beklenmektedir. Örneğin reklam kampanyasının başarılı olup olmadığ satıştaki artışla pozitif ilişkilendirebilmektedir ve bu yüzden tek kuyruklu t testi uygulana- bilmektedir. Örneğin başarı değerlendirilmesinde öğrencinin sınav notlarının azalması veya artması analizci için önemli olacağından tek kuyruk yerine çift kuyruk $t$ testi uygulanması önemli bir hal almaktadır. SPSS programında üç farklı t testi bulunmaktadır. Bunlar independent samplest test paired samplest test, one samplest test olarak programda yer almaktadırlar. Bu çalışmada verilere göre parametrik testlerden one-way anova testi kullanılmıştır.

Parametrik olmayan testler arasında Ki kare, MannWhitney U, Wilcoxon Sign Ranks, Kruskal Wallis gibi testler yer almaktadır. Ki kare testi nonparametrik testler içinde en yaygın olarak kullanılan testtir. Uygunluk ve bağımsızlık olarak iki türde uygulanabilmekte uygunluk testi verilerin dağılıma uygunluğunu test ederken, bağımsızlık testi ise iki bağımsız değişken arasındaki ilişkiyi ölçmektedir. Veri seti normal dağılıma uygunluktan çok uzak ise ortalamalar arası farkı bulmak için t testi uygulanamamakta bunun yerine $\mathrm{t}$ testinin parametriği olan MannWhitney U testi kullanılmaktadır. Aynı şekilde veriler yine normal dağılıma uygun değilse ve veriler çok çarpıksa $t$ testi yerine Wilcoxon işaret testi kullanılabilmektedir. Kruskal Wallis testi de normal dağılıma uygunluk göstermeyen üç ve üzeri grubun ortalamaları arasındaki farklılığın anlamlılı̆̆ının test edilmesi için kullanılmaktadır. Kruskal Wallis testi anova parametrik testinin nonparametrik karşılığı olarak bilinmektedir ve parametrik olmayan testler arasında oldukça güçlü bir test olarak yer almaktadır. Bu çalışmada parametrik olmayan testlerden Kruskal Wallis testi kullanılmıştır [24-28].

\section{UYGULAMA}

Bu çalışmada bir çelik fabrikasında ortaya çıkan iş kazalarının fabrikanın hangi bölümünde hangi çalışma saatinde, hangi vardiyada gerçekleştiği, kazayı geçiren işçinin kıdeminin ne olduğu ile ortaya çıkan kazanın şiddeti ara- 
sında anlamlı bir ilişkinin var olup olmadığı araştırılmışıır. Bu araştırma için IBM SPSS Statistic 17.0 programı kullanılarak analizler gerçekleştirilmiştir.

Araştırmanın amacına ulaşabilmek için kaza şiddeti ve diğer faktörlerle ilgili aşağıdaki hipotezler kurulmuştur.

H0: Kaza şiddeti iş̧inin kıdemine göre farklılık göstermemektedir.

H1: Kaza şiddeti işçinin kıdemine göre farklılık göstermektedir.

H2: Kaza şiddeti kazanın gerçekleştiği bölüme göre farklılık göstermemektedir.

H3: Kaza şiddeti kazanın gerçekleştiği bölüme göre farklılık göstermektedir.

H4: Kaza şiddeti kaza saatine göre farklılık göstermemektedir.

H5: Kaza șiddeti kaza saatine göre farklılık göstermektedir.

H6: Kaza şiddeti vardiyaya göre farklılık göstermemektedir

H7: Kaza şiddeti vardiyaya göre farkllılık göstermektedir.

$\mathrm{Bu}$ çelik fabrikası için işçinin kıdemi 0-6,6-12,12-18 yıl olarak belirlenmiştir. Kazaların gerçekleștiği bölümler dolu hat, ortak hat, boru hattı ve yay hattı olmak üzere dört bölümden oluşmaktadır. Kaza saatleri 8 saatlik bir çalışmayı kapsamaktadır. Bu iş yerinde 3 vardiya çalışılmaktadır. Kaza şiddetleri de az, orta ve çok olmak üzere gruplandırılmışlardır. Toplamda 99 adet veri incelenmiştir. Araştırmada elde edilen bulgular Tablo 2 ve Tablo 3 'te gösterilmektedir.

Çalışma analizleri;

- Kaza şiddeti ve kıdem arasındaki ilişki

- Kaza şiddeti ve bölüm arasındaki ilişki

- Kaza şiddeti ve kaza saati arasındaki ilişki

- Kaza şiddeti ve vardiya arasındaki ilişki

olarak dört başlık alıında gerçekleştirilmiştir.
Tablo 2: Verilerin programda analiz edilmesiyle ortaya çıkan frekansları

\begin{tabular}{lcc}
\hline & Ortaya çı & Frekans(n) \\
\hline Kıdem & $0-6$ yıl & 59 \\
& $6-12$ yıl & 23 \\
& $12-18$ yıl & 17 \\
\hline Kazanın Gerçekleştiği & Dolu Hat & 33 \\
Bölüm & Boru Hat & 16 \\
& Ortak Hat & 13 \\
& Yay Hatt & 37 \\
\hline \multirow{4}{*}{ Kaza Saati } & 1 & 18 \\
& 2 & 8 \\
& 3 & 14 \\
& 4 & 13 \\
& 5 & 12 \\
Vardiya & 6 & 16 \\
& 7 & 10 \\
& 8 & 8 \\
\hline Kazanın Şiddeti & 1 & 56 \\
& 2 & 23 \\
& 3 & 20 \\
\hline
\end{tabular}

Tablo 3: Verilerin ortalama ve standart sapma değerleri

\begin{tabular}{lcc}
\hline & Ortalama & Standart Sapma \\
\hline Kıdem & 1,58 & 0,771 \\
Bölüm & 2,55 & 1,296 \\
Kaza Saati & 4,22 & 2,252 \\
Vardiya & 1,64 & 0,801 \\
Şiddet & 1,68 & 0,867 \\
\hline
\end{tabular}

\section{A. Kaza Şiddeti ve İşçinin Kıdemi Arasındaki İlişki}

İlk olarak hangi testin kullanılacağına karar vermek için varsayımlar kontrol edildi. İlk varsayım olan verilerin normal dağılıma uygunluğu kontrol edildi. Normal dağılıma uygunluk için Skewness ve Kurtosis değerleri yani çarpıklık ve basıklık değerlerine bakıldı. Kolmogorov-Smirnov ve Shapiro- Wilk testlerinin Sig değerlerine bakılmadı çünkü veri sayımız arttıkça bu testler genelde normal dağılıma uygun değildir şeklinde sonuç vermektedir. Verilerimiz oldukça fazla olduğu için bu testlerden etkilenerek normal dağılıma uygunluğuna karar verilirse parametrik testlere 
göre daha güçsüz olan nonparametrik testler kullanılması gerekli olmaktadır ve bu analizimizin gücünü düşürebilmektedir. İşçinin kıdemi için basıklık ve çarpıklık değerleri Tablo 4 'te verilmektedir.

Tablo 4: İşçi kıdeminin normallik testi ve varyans homojenliği

\begin{tabular}{lcc}
\hline Kıdem & Statistic & Std.Error \\
\hline Skewness & 0,902 & 0,243 \\
Kurtosis & $-0,719$ & 0,481 \\
Levene Statistics & 0.487 & \\
df1 & 2 & \\
df2 & 96 & \\
Sig. & 0.616 & \\
\hline
\end{tabular}

Tablo 4 'te görüldüğü üzere basıklık ve çarpıklık değerleri +2 ve -2 arasında olduğu için verilerin normal dağılıma uygun olduğuna karar verilmektedir [29].

İkinci varsayım olarak örneklem sayısı 30' dan büyük olduğu ve üçüncü varsayım olan verilerin ölçümle elde edildiği bilinmektedir.

Dördüncü varsayım olarak verilerin varyanslarının homojen olarak dağılıp dağılmadığına bakılmıştır. Hipotezler \%95 güven aralığında aşağıdaki gibi kurulmuştur.

$\mathrm{H}_{00}$ : Varyanslar homojendir.

$\mathrm{H}_{11}$ : Varyanslar homojen değildir.

Tablo 4'te görüldüğü üzere Sig değeri 0,05'ten büyük olduğu için H00 reddedilmez ve varyansların homojen olduğu kabul edilmektedir.

Yapılan analizler sonucunda Oneway-ANOVA testinin veriler için uygun olduğuna karar verilmektedir. Bu analiz için hipotezler aşağıdaki gibidir:

$\mathrm{H}_{0}$ : Kaza şiddeti işçinin kıdemine göre farklılık göstermemektedir.

$\mathrm{H}_{1}$ : Kaza şiddeti işçinin kıdemine göre farklılık göstermektedir.
Tablo 5: İşçi kıdemi için uygulanan anova

\begin{tabular}{lrrrrr}
\multicolumn{6}{c}{ test sonuçlar1 } \\
\hline & $\begin{array}{c}\text { Sum of } \\
\text { Squares }\end{array}$ & \multicolumn{1}{c}{ df } & $\begin{array}{c}\text { Mean } \\
\text { Square }\end{array}$ & F & Sig. \\
\hline $\begin{array}{l}\text { Between } \\
\text { Groups }\end{array}$ &, 889 & 2 &, 445 &, 745 &, 477 \\
$\begin{array}{l}\text { Within } \\
\text { Groups }\end{array}$ & 57,293 & 96 &, 597 & & \\
\hline Total & 58,182 & 98 & & & \\
\hline
\end{tabular}

Tablo 5'te görülmekte olan Sig değeri 0,05' ten büyük olduğu için H0 hipotezi kabul edilmektedir. Kaza şiddeti işçinin kıdemine göre farklılık göstermemektedir.

\section{B. Kaza Şiddeti ve Kazanın Gerçekleştiği Bölüm Ara- sındaki İlişki}

Kaza şiddeti ve kazanın gerçekleştiği bölüm arasındaki ilişkinin tespiti için verilerin normal dağılıma uygunluğuna bakıldı. Tablo 6’ da görüldüğü üzere basıklık ve çarpıklık değeri +2 ve -2 arasında olduğu için verilerin normal dağılıma uygun olduğuna karar verildi.

Tablo 6: Kazanın gerçekleştiği bölümün normallik testi ve varyans homojenliği

\begin{tabular}{lcc}
\hline Bölüm & Statistic & Std.Error \\
\hline Skewness & $-0,045$ & 0,243 \\
Kurtosis & $-1,725$ & 0,481 \\
Levene Statistic & 0,862 & \\
df1 & 2 & \\
df2 & 96 & \\
Sig. & 0,426 & \\
\hline
\end{tabular}

Örneklem sayısı 30' dan büyük olduğu için ikinci varsayım kabul edildi. Fakat kazanın gerçekleştiği bölüm verileri ölçümle elde edilmediği için üçüncü varsayım ihlal edildi. Dördüncü varsayım için Tablo 6’ daki Sig değerine bakıldı ve $\mathrm{H}_{00}$ reddedilmedi. Yani varyansların homojen olduğu kabul edildi.

Varsayımlardan en az biri reddedildiği için Tablo 3'e göre nonparametrik bir test olan Kruskal-Wallis testi verilere uygulandı. Bu test için hipotezler aşağıdaki gibidir. 
$\mathrm{H}_{2}$ : Kaza şiddeti kazanın gerçekleştiği bölüme göre farklılık göstermemektedir.

$\mathrm{H}_{3}$ : Kaza şiddeti kazanın gerçekleştiği bölüme göre farklılık göstermektedir.

Tablo 7: Kazanın gerçekleştiği bölümün Kruskal Wallis test sonucu

\begin{tabular}{ll}
\hline & Bölüm \\
\hline Chi-Square & 1,953 \\
df & 2 \\
Asymp.Sig. & 0,377 \\
\hline
\end{tabular}

Tablo 7’ de görülen Sig değerine göre $\mathrm{H}_{2}$ hipotezi reddedilmedi. Kaza şiddetinin kazanın gerçekleştiği bölüme farklılık göstermediği kabul edildi.

\section{Kaza Şiddeti ve Kazanın Çalışmanın Kaçıncı Saatin- de Gerçekleştiği Arasındaki İlişki}

Veriler Tablo 8' de görüldügüü üzere basıklık ve çarpıklık değerlerinden dolayı normal dağılıma uygundur kararı verildi.

Tablo 8: Kaza saatinin normallik testi ve

\begin{tabular}{lcc}
\multicolumn{3}{c}{ varyans homojenliği } \\
\hline Kaza Saati & Statistic & Std.Error \\
\hline Skewness & 0,023 & 0,243 \\
Kurtosis & $-1,173$ & 0,481 \\
Levene Statistic & 0,796 & \\
df1 & 2 & \\
df2 & 96 & \\
Sig. & 0,454 & \\
\hline
\end{tabular}

Varyans homojenliği için Tablo 8' de görüldüğü üzere Sig değeri 0,05 'ten büyük olduğu için $\mathrm{H}_{00}$ hipotezi yani varyansların homojen olduğu kabul edildi.

$\mathrm{H}_{4}$ : Kaza şiddeti kaza saatine göre farklılık göstermemektedir.

$\mathrm{H}_{5}$ : Kaza şiddeti kaza saatine göre farklılık göstermektedir.

Tüm varsayımlar kabul edildiği için ANOVA testi uygulandı. Test sonuçlarına göre Tablo 9' da görüldüğü üzere $\mathrm{H}_{4}$ hipotezi reddedildi ve $\mathrm{H}_{5}$ alternatif hipotezi kabul edil- di. Bu hipoteze göre kaza şiddeti kaza saatine göre farklılık göstermektedir.

Tablo 9: Kaza saati verilerini anova testi sonuçları

\begin{tabular}{llllll}
\hline & $\begin{array}{l}\text { Sum of } \\
\text { Squares }\end{array}$ & df & $\begin{array}{l}\text { Mean } \\
\text { Square }\end{array}$ & F & Sig. \\
\hline $\begin{array}{l}\text { Between } \\
\text { Groups }\end{array}$ & 30,364 & 2 & 15,182 & 3,123 &, 049 \\
$\begin{array}{l}\text { Within } \\
\text { Groups }\end{array}$ & 466,747 & 96 & 4,862 & & \\
\hline Total & 497,111 & 98 & & & \\
\hline
\end{tabular}

\section{Kaza Şiddeti ve Kazanın Kaçıncı Vardiyada Olduğu} İle İlişkisi

Kazanın gerçekleştiği vardiyanın verilerinin normal dağılıma uygun olup olmadığını görmek ve ilk varsayımın kontrolünü gerçekleştirmek için normallik testi uygulandı. Tablo 10'da görüldüğü üzere basıklık ve çarpıklık değerlerinden verilerin normal dağılıma uygun olduğu kabul edildi.

Tablo 10: Kazanın gerçekleştiği vardiyanın verilerinin normal dağılıma uygunluğu ve varyans homojenliği

\begin{tabular}{lcc}
\hline Vardiya & Statistic & Std.Error \\
\hline Skewness & 0,757 & 0,243 \\
Kurtosis & $-1,021$ & 0,481 \\
Levene Statistic & 3,831 & \\
df1 & 2 & \\
df2 & 96 & \\
Sig. & 0,025 & \\
\hline
\end{tabular}

Tablo 10’ dan görüldüğü üzere Sig. Değeri 0,05 ' ten küçük olduğu için $\mathrm{H}_{00}$ hipotezi reddedildi ve onun alternatifi olan $\mathrm{H}_{11}$ kabul edildi. Vardiya verileri için varyanslar homojen değildir. Varsayımlardan en az biri ihlal edildiği için nonparametrik bir test olan Kruskal Wallis testi uygulandi.

Tablo 11: Vardiya verileri için uygulanan Kruskal Wallis test sonucu

\begin{tabular}{ll}
\hline & Vardiya \\
\hline Chi-Square & 5,027 \\
df & 2 \\
Asymp.Sig. & 0,081 \\
\hline
\end{tabular}


Tablo 11'de görülen Sig. Değeri 0,05'ten büyük olduğu için $\mathrm{H}_{6}$ hipotezi kabul edildi. Kaza şiddeti vardiyaya göre farklılık göstermemektedir.

H6: Kaza şiddeti vardiyaya göre farkl1lık göstermemektedir

H7: Kaza şiddeti vardiyaya göre farklılık göstermektedir.

\section{IV.SONUÇ}

Yapılan çalışma ile sanayi bölgesinde bulunan ve çelik üreten bir fabrikada ortaya çıkan iş kazaları verileri kullanılarak iş kazalarının şiddeti ile iş kazalarının gerçekleştiği bölüm, çalışma saati, vardiya ve işçinin kıdemi arasında ilişki olup olmadığı istatistiksel analizlerle değerlendirilmiştir. Gün geçtikçe önemini arttıran iş güvenliği ve sağlığı kavramı işletmeler için de çok önemli bir fonksiyon olmaktadır. Ne yazık ki ne kadar çok önlem alınsa bile bazı durumlarda yine de iş kazaları meydana gelmektedir. İş kazaları tamamen engellenemez fakat can kayıpları ya da kazanın maddi manevi olarak verdiği zararlar minimum seviyeye indirilebilmektedir. Bunun için birçok koşul, davranış değerlendirilmeli ve mümkün olduğunca çok tedbirler alınmalıdır.

Yapılan çalışmada bir çelik fabrikası ele alınmıştır. $\mathrm{Bu}$ fabrikada denge çubuğu ve helisel yay üretimi yapılmakta ve üretim için dört adet hat bulunmaktadır. Bu hatlar dolu hat, boru hattı, ortak hat ve yay hattı olmak üzere bölümlendirilmişlerdir. Kazalar bu hatlardaki bölümlerden meydana gelmişlerdir. Her hattın çalışma prensibi farklı ve hatlarda bulunan makineler birbirinden farklı özellikler taşıdıkları için iş kazalarının bu hatlarda çıkmasıyla şiddetleri arasında bir ilişki olup olmadığı değerlendirilmiştir. İş kazaları işçinin tecrübesiyle ilişkili mi yoksa tamamen tesadüfsel olarak mı gerçekleşiyor sorusuna cevap bulmak için de işçi kıdemleri ile iş kazaları şiddeti arasındaki ilişki istatistiksel testler uygulanarak analiz edilmiştir. İş kazalarının birçok nedeni olabildiği gibi bu nedenlerden birisi de çalışma saatleridir. Sosyal Güvenlik Kurumu 2018 verilerine göre en fazla iş kazasının olduğu saatler öğle arasından hemen önce sabah 10-11 olduğu görülmektedir [30]. Verilerin alındığı çelik fabrikasında da iş kazalarının şiddeti ile kazanın gerçekleştiği saat ve vardiya arasında bir ilişki olup olmadığı değerlendirilmiştir.

Uygulanan istatistiksel testler sonucunda iş kazalarının şiddeti ile kazanın çalışmanın hangi saatinde gerçekleştiği arasında anlamlı bir ilişki bulunmaktadır. Bunun yanı sıra kazanın şiddeti iş̧̧inin kıdemine, kazanın gerçekleştiği bölüme, ve kazanın gerçekleştiği vardiyaya göre herhangi bir farklılık göstermemektedir sonucuna ulaşılmıştır. İş kazalarının şiddeti ile kazanın çalışmanın hangi saatinde gerçekleştiği haricinde belirlenen faktörlerle arasında anlamlı bir ilişki bulunmamaktadır. Bu durum çalışanların motivasyonundan kaynaklanabilmektedir. Örneğin bir çalışan dikkatinin çok dağınık olduğu çalışma saati içerisinde geçirdiği iş kazasından çok daha ağır yaralar alabilir. Öneri olarak çalışanların hangi saatlerde ağır iş kazaları geçirdikleri verilerin frekansına bakılarak belirlendikten sonra o saatlerde çalışana mola verilerek dikkatini toplaması sağlanabilir ya da tam dikkatlerin dağıldığı saatlerde çalışanın motivasyonunu arttırmak için etkinlikler uygulanabilir. Çalışan özellikle o saatlerde bir işs sağlığı ve güvenliği uzmanı tarafından daha dikkatli şekilde denetlenerek gerekilen uyarılar çalışana sunulabilir. Çalışanlara iş kazaları, iş güvenliği ve sağllğı hakkında daha fazla eğitimler düzenleyerek ve bu eğitimlerle kurumda bir güvenlik kültürü oluşturarak iş güvenliğine verilen önem arttırlabilir. İnsan hayatı çok önemli olduğu için sürekli olarak bu konu hakkında analizler ve çalışmalar gerçekleştirilmeli ve iş güvenliği sağlanmaya devam ettirilmelidir. 


\section{KAYNAKÇA}

[1] Çakı C., Arpa M. (2018), "İş Kazası Diye Bir Şey Yoktur”: Kanada İş Güvenliği Reklamları Üzerine İnceleme, Çalışma İlişkileri Dergisi, 9(2),75-87.

[2] Bingöl S.(2010), Nilüfer Organize Sanayi Bölgesindeki Metal Sanayi İş Koluna Ait İşyerlerinde İş Kazası Sıklı̆ı ve Etkileyen Bazı Etmenler, Uludağ Üniversitesi, Tıp Fakültesi, Uzmanlık Tezi, Bursa.

[3] Camkurt M.Z.(2007), İşyeri Çalışma Sistemi ve İşyeri Fiziksel Faktörlerinin İş Kazaları Üzerindeki Etkisi, TÜHİS İş Hukuku ve İktisat Dergisi ,20(6),80-106.

[4] Ceylan H.(2011),Türkiye'deki İş Kazalarının Genel Görünümü Ve Gelişmiş Ülkelerle Kıyaslanması, International Journal of Engineering Research and Development,3(2),18-24.

[5] Ekinci H.K.(2020), Yapı İşlerinde İş Sağlığı Güvenliği Uygulamalarının İncelenmesine Yönelik Örnek Çalışma: Ankara-Sivas Demiryolu Projesi, Sivas Cumhuriyet Üniversitesi, Fen Bilimleri Enstitüsü, İş Sağlığı ve Güvenliği Anabilim Dalı, Yüksek Lisans Tezi, Sivas.

[6] Uzun İ.M.(2020), İnşaat Sektörüne Özgü İş Sağlığı Güvenliği Yönetim Sisteminin Aksiyomlarla Tasarımı ve Performans Ölçümü İçin Yeni Bir Model Önerisi, Yıldız Teknik Üniversitesi, Fen Bilimleri Enstitüsü, Endüstri Mühendisliği Anabilim Dalı, Doktora Tezi, İstanbul.

[7] Gürsoy T.(2019), Çalışanların İş Sağlığı ve Güvenliği Eğitimlerinin Değerlendirilmesi, Süleyman Demirel Üniversitesi, Fen Bilimleri Enstitüsü, Yapı Eğitimi Anabilim Dalı, Yüksek Lisans Tezi, Isparta.

[8] Güllüoğlu E.N., Güllüoğlu A.N.(2019), Türkiye İnşaat Sektöründe İstihdam ve İş Kazalarının Analizi, Karaelmas İş Sağlığı ve Güvenliği Dergisi, 3(2), 6581.

[9] Korkmaz S.(2017), İnşaat Sektöründe İş Kazası Araştırmalarında Kusur Dağılımı, Düzce Üniversitesi, Fen Bilimleri Enstitüsü, İnşaat Mühendisliği Anabilim Dalı, Yüksek Lisans Tezi, Düzce.

[10] Yıldırım N.(2019), Kireç Üretim Sektöründe İş Sağlığı Güvenliği ve Çevre Yönetim Sistemlerinin Uygu- lanması, Sakarya Üniversitesi, Fen Bilimleri Enstitüsü, Çevre Mühendisliği Anabilim Dalı, Yüksek Lisans Tezi, Sakarya.

[11] Halıı A.K., İşleyen S.K.(2019), Elektrik Kaynaklı İş Kazalarına Farklı Bir Bakış: Metal Sektöründe Yaşanan Kaza Sebeplerinin Önceliklendirilmesi, Karaelmas İş Sağlığı ve Güvenliği Dergisi, 3(1), 1-12.

[12] Kuşdemir B.(2018), Tekirdağ İlinde Bazı Mobilya İşletmelerinde İş Sağlığı Güvenliği, Artvin Çoruh Üniversitesi, Fen Bilimleri Enstitüsü, Orman Endüstri Mühendisliği Anabilim Dalı, Yüksek Lisans Tezi, Artvin.

[13] Yeşilgöz P.(2018), Dökümhanelerde İş Sağlığı Güvenliği ve Pratik Uygulamalar, Marmara Üniversitesi, Fen Bilimleri Enstitüsü, İş Güvenliği Anabilim Dalı, Yüksek Lisans Tezi, İstanbul.

[14] Ertürk Ö.(2017), Bir Fabrikada Çalış̧anların Psikolojik Sermaye ve Uykululuk Düzeylerinin İş Kazası Oluşumuna Etkisinin İncelenmesi, Sakarya Üniversitesi, Sağlık Bilimleri Enstitüsü, Hemşirelik Anabilim Dalı, Yüksek Lisans Tezi, Sakarya.

[15] Kazancı Yabanova E.(2016), Gece Vardiyasının İşçiler Üzerinde Yarattığı Fizyolojik, Psikolojik, Sosyolojik ve İş Kazası Etkilerine İlişkin Bir Alan Araştırması, Çanakkale Onsekiz Mart Üniversitesi, Sosyal Bilimler Enstitüsü, Çalışma Ekonomisi ve Endüstri İlişkileri Anabilim Dalı, Yüksek Lisans Tezi, Çanakkale.

[16] Kanlıoğlu Özkul A.(2015), Basınçlı Gaz Tüpleri Kullanım ve Depolanmasının İş Sağlığı Güvenliği Açısından İncelenmesi ve Çözüm Önerileri, Gazi Üniversitesi, Fen Bilimleri Enstitüsü, Kimya Mühendisliği Anabilim Dalı, Yüksek Lisans Tezi, Ankara.

[17] Özçatalbaş Ö.(2014), İş Kazası Nedenlerinin Kök Sebep Analizi İle İncelenmesi, Çukurova Üniversitesi, Fen Bilimleri Enstitüsü, Yüksek Lisans Tezi ,Adana.

[18] Gülhan B.(2008), Bir Ağır Metal Üretim Fabrikasında Çalışanların İş Kazası Geçirme Sıklığı ve İlişkili Etmenler, Gazi Üniversitesi, Sağlık Bilimleri Enstitüsü, İşçi Sağlığı ve İş Güvenliği Anabilim Dalı, Yüksek Lisans Tezi, Ankara.

[19] Karabulut Y.(2018), Kamu Kurumlarında İş Sağlığı Güvenliği Mevzuatının Uygulama Düzeyinin Değer- 
lendirilmesi, Üsküdar Üniversitesi, Sağlık Bilimleri Enstitüsü, İş Sağllğı ve Güvenliği Anabilim Dalı, Yüksek Lisans Tezi, İstanbul.

[20] Gül D.(2017), Türkiye'de İş Sağlığı Güvenliği Mevzuatları Çerçevesinde Ortak Sağlık ve Güvenlik Birimlerinin (OSGB) Karşılaştıkları Sorunlar ve Çözüm Önerileri, Gaziantep Üniversitesi, Sosyal Bilimler Enstitüsü, İş Sağlı̆̆ı ve Güvenliği Anabilim Dalı, Yüksek Lisans Tezi, Gaziantep.

[21] Cengiz E., Akyüz İ., Tuzcuoğlu A., Bilimsel Araştırma Teknikleri, İstanbul Üniversitesi Açık Ve Uzaktan Eğitim Fakültesi, Kamu Yönetimi Lisans Programı.

[22] İştar N.(2016), Parametrik Olmayan İstatistiksel Testlerde Çoklu Karşılaşırımalar, Ondokuz Mayıs Üniversitesi, Fen Bilimleri Enstitüsü, Yüksek Lisans Tezi, İstatistik Anabilim Dalı, Samsun.

[23] Sari M.(2017),Veri Analizinde Doğru İstatistiksel Testin Bilgisayar Yardımıla Seçilmesi, Karadeniz Teknik Üniversitesi, Fen Bilimleri Enstitüsü, İstatistik ve Bilgisayar Bilimleri Anabilim Dalı, Yüksek Lisans Tezi, Trabzon.

[24] Günel A.(1971), İstatistiksel Testler: Hangisi, Ne Zaman?, İstanbul Üniversitesi Orman Fakültesi Dergisi, 21(1),238-254.

[25] Demir E., Saatçioğlu Ö.,İmrol F.(2016), Uluslararası Dergilerde Yayımlanan Eğitim Araştırmalarının Normallik Varsayımları Açısından İncelenmesi, Curr Res Educ, 2(3) ,130-148.

[26] Karagöz Y.(2010), Nonparametrik Tekniklerin Güç Ve Etkinlikleri, Elektronik Sosyal Bilimler Dergisi,9 (33), 18-40.

[27] Y.lmaz Y. ,Yllmaz Y.(2005), Parametrik Olmayan Testlerin Pazarlama Alanındaki Araşıtırmalarda Kullanımı: 1995-2002 Arası Yazın Taraması, Dokuz Eylül Üniversitesi Sosyal Bilimler Enstitüsü Dergisi, 7 (3),177-199.

[28] Turanlı Ö.H., Turanlı M.(2000), Parametrik Ve Parametrik Olmayan Testler, Marmara Üniversitesi, Sosyal Bilimler Enstitüsü, Ekonometri Anabilim Dal1, İstatistik Bilim Dalı, Yüksek Lisans Tezi, İstanbul.

[29] George, D., \& Mallery, M. (2010). SPSS for Windows Step by Step: A Simple Guide and Referen- ce, 17.0 update (10a ed.) Boston: Pearson

[30] Türkiye Cumhuriyeti Sosyal Güvenlik Kurumu, http://www.sgk.gov.tr/wps/portal/sgk/tr/kurumsal/ istatistik/sgk_istatistik_yilliklari (erişim tarihi: Mayıs 2020) 